\title{
Introduction: White-Collar and Corporate Crime in Asia
}

\author{
Henry N. Pontell • Gilbert Geis
}

Received: 24 April 2010 / Accepted: 12 May 2010 /

Published online: 3 June 2010

(C) The Author(s) 2010. This article is published with open access at Springerlink.com

\begin{abstract}
In this introduction to this special issue of the Journal we broadly consider the problem of white-collar and corporate crime in Asia. Official reports from China show the pervasiveness of current problems and the inherent dangers underlying continued economic growth and reforms. We also consider evidence bearing on the idea that Japan's remarkably low rate of common crime is likely eclipsed by the level of white-collar and corporate crime, and briefly discuss the institutionalization of economic crime in South Korea. Issues related to the lack of study of white-collar and corporate lawbreaking in Asia are also addressed. Finally, we introduce the papers and topics of this special issue, which include comparative research on cybercrime, the enforcement of intellectual property violations, accounting fraud, financial crime, and offenses in the mutual fund industry.
\end{abstract}

Keywords White-collar crime $\cdot$ Corporate crime $\cdot$ Financial fraud $\cdot$ Comparative criminology

The worst global financial crisis in history serves as a backdrop to this special issue of the Journal. The specter of white-collar and corporate crime looms large as countries throughout the world grapple with depressed economic conditions that have their roots in the home loan industry and the irresponsible and often criminal behavior of Wall Street financiers. Subprime mortgages were marketed to less than creditworthy borrowers. Many of these loans were based on fraudulent financial information regarding purchasers' income and assets. They were packaged into complex securities and derivatives, and were offloaded throughout the world. Insurance on these securities in the form of credit default swaps (CDSs) constituted counter bets which were bought for pennies on the dollar. When the original loans inevitably went bad, a financial maelstrom reverberated throughout the global economy. The effects on the Asia-Pacific region included reduced demand for many of the area's major exports, particularly tourism, manufacturing, and commodities.

H. N. Pontell $(\bowtie) \cdot$ G. Geis

Department of Criminology, Law and Society, School of Social Ecology, University of California, Irvine, CA 92697-7080, USA

e-mail: pontell@uci.edu 
Government revenues were also reduced as demand for migrant labor in developed and emerging economies slowed down, and overseas workers were no longer remitting money to families in their homeland.

Corruption, a universal institutional phenomenon, is especially pervasive in developing and transitional societies (Yu 2008; Zimring and Johnson 2007). China, the most populous country in the world and a growing superpower, has experienced both unprecedented economic development during the past two decades and attendant rampant corruption at all levels in the government and in the private sector (Yu 2008). Zhang et al. (2008:127) have pointed out that, "White-collar crime and official corruption in particular have been a serious concern in China and have attracted wide attention during the course of the nation's economic reform." Campaigns to control corruption are a feature of Chinese life and often involve draconian penalties. In recent years, there have been reports that death sentences for commercial fraud have increased because of a burgeoning trade in body parts that can be harvested under controlled conditions from offenders who are executed (McGivering 2006).

Olivia Yu (2008) has reviewed theories offered to explain the causes of Chinese corruption and economic criminality, and suggests that the escalation in the number of these problems is an unintended consequence of reform policies. The phenomenon can be interpreted in terms of a number of prevalent criminological perspectives, including: (1) social control theory which emphasizes the importance of conditions such as attachment to parental values in preventing individuals from engaging in illegal activities; (2) anomie theories which view crime as resulting from normative deregulation, social structural strain, and lack of legitimate opportunities combined with an overriding cultural ethos that stresses the need for wealth and its associated acquisitions; (3) rational choice models which consider the role of criminal opportunities in motivating and enabling particular forms of crime; and (4) cultural explanations that focus on traditions or values among persons from different backgrounds and varying experiences (Yu 2008:167).

Research in China on the subject of financial fraud, as in most countries, has been sparse due to the lack of large and systematic data sources and a related political unwillingness to fund major studies. The occurrence of white-collar crime often remains under a cloak of official secrecy for at least two reasons: first, governments do not like to broadcast an image of their country as riddled with upper-class law-breaking, and second, the very officials themselves may well be involved in illegal schemes and they do not desire to alert the public to wrongdoing in other high places.

Nonetheless, some statistics and case reports meant to show diligent law enforcement and offer lessons in the danger of defying regulations are sometimes issues. A sampling of offenses reported by the Chinese government depicts the broad nature of current problems and the inherent dangers underlying continued economic growth and reforms. In 2007, for example, it was reported that Chinese prosecutors investigated 43,757 government officials for job-related crimes in the previous year alone. Over 35,000 of them involved some form of corruption, bribe-taking or embezzlement of public funds, while just over 8,700 of them entailed abuse of power. About 31,000 cases were prosecuted in the same year, with the government retrieving 4.56 billion yuan (about US\$555 million) from purloined funds. The government also reported that 4,414 state officials were investigated for corruption or bribetaking in road construction, urban reconstruction, medicine purchase and land requisition, and 10,407 employees of state-owned enterprises (SOE) were suspected of embezzling public funds. Moreover, 9,476 administrative and judicial personnel were under investigation for charges of power abuse, dereliction of duties, and taking bribes, and almost 3,000 high-level officials were reprimanded for major malpractice and negligence leading to grim traffic, coal mine and environmental pollution accidents (BBC 2005a). 
Underlining the increasing impact of white-collar law breaking in the world's largest country, China's Ministry of Public Security reported that the number of violent crimes had declined while economic crimes - especially those involving fake products and smugglingrose in the first six months of 2007. Murder, rape, arson, and bomb attacks decreased 9.1, 2.9, 7.9 and $27 \%$, respectively, from the previous year, while the number of known economic crimes increased by $10 \%$. "Cases involving the production and selling of fake or substandard products, smuggling and disruption of market order saw the biggest increases," it was reported (Chinadaily.com.cn. 2006). In addition, there were 3,695 financial fraud cases and 1,094 intellectual property rights violation cases, up 14.3 and $2.7 \%$ respectively. The rise in economic crimes had shown a steady increase over the past few years. Some speculated that the rise will continue as China continues to transition from a planned to a free market economy (Chinadaily.com.cn. 2006).

China's financial system has also been subject to recent scandal, and transparency in accounting - as is the case in the rest of the world - remains a key problem. In 2005, the Chinese government reported that there were 240 major criminal violations in China's stateowned commercial banks in the first half of that year, accounting for one-third of the country's total bank scandals and a total loss of 1.6 billion yuan ( $\$ 198$ million). The emergence of the scandals was reportedly due to reform of the country's banking system and correspondingly intensified government oversight and policing (BBC 2005b).

China reports great difficulty in locating major suspects who have escaped the country, and major efforts are being made to locate the fugitives and return them to the country. Government figures show that over 800 individuals accused of embezzling more than 70 billion yuan ( $\$ 8.75$ billion) had fled the country as of 2006 , and that about 500 were still at large. Even when criminal suspects are located, many foreign governments are unwilling to send them back to China because they may face the death penalty, a punishment that in most countries has either been abolished or is inflicted only on murderers. To help ameliorate the problem, China has established agreements with many countries that stipulate that suspects will not be executed if they are returned to the PRC to stand trial (Chinadaily.com.cn 2006).

In the case of Japan, criminological interest traditionally has been focused on the country's much-heralded low crime rate. Given that the depth of the problem of whitecollar crime goes far deeper than adjudicated cases, Japan's remarkably low rate of common crime is likely eclipsed by the level of white-collar and corporate crime. Numerous cases abound of egregious wrongdoing by banks, corporations, and politicians at the highest levels of government. In an examination of one newsworthy incident, the Cosmos Recruit scandal which involved the widespread bribery of Japanese politicians, Kerbo and Inoue (1990:148) concluded that such behavior is rather common in business and political activities. More recently, in the wake of the corporate and accounting scandals in the U.S., Japan was wracked by a series of similar scandals in the mid-2000s that involved some of the largest and most highly respected companies in the country (Pontell and Geis 2007).

Though Sutherland's ground-breaking monograph, White Collar Crime, published ten years after his presidential address, was translated into Japanese (Sutherland 1955), the subject has produced only a slight amount of scholarly work in Japan. Criminological study in Japan is largely a legal pursuit, and juridical scholars are less inclined than social scientists to engage in the kind of muckraking enterprise regarding upper class and corporate lawbreaking that in considerable measure characterized the work of Sutherland and his followers in the United States. Elements of Japanese culture, including temerity in the face of authority, have probably also been responsible for the general neglect of scholarship focusing on white-collar offenses. 
Johnson (2003) notes some of Japan's "intractable problems," including trillions of dollars in unrecoverable bank loans, nuclear accidents and cover-up, and structural corruption. He points out that compared to the U.S., laws directed against the wrongdoing of powerful people and organizations are weaker in Japan. "In the words of Jonathan Swift, this disparity means that Japanese law is like a cobweb, catching small flies but letting wasps and hornets break through" (Johnson 2003:778).

This special issue concerns important aspects of economic crime in China and Japan. Although the two countries by far comprise the largest proportion of the Asian economy, this in no way implies that they harbor the most serious problems of economic law-breaking in Asia. In South Korea, for example, executives at major companies have been convicted of such crimes as embezzlement, accounting fraud, and breach of duty, have sometimes escaped conviction, or, if convicted, had their sentences reduced, and have returned to their jobs, while some never had to leave them. According to one expert, "Most of the chairmen at the 10 biggest companies are convicts" (Glionna 2010: A4). Last summer, the chairman of Samsung Electronics, Lee Kun-hee, was given a suspended sentence for tax evasion after he was convicted of hiding $\$ 4$ billion. In December, he was pardoned by South Korea's President who wanted him to help with South Korea's bid for the 2018 Winter Olympics. Among the major reasons for such leniency of white-collar lawbreaking in the country is the power of the large corporate conglomerates known as chaebols. Their boardrooms are dominated by family members who have near-royalty status (Glionna 2010). The economic progress that is influenced by such families produces positive political legacies for those in power and who are thus unwilling to challenge them. The result is that South Korean business leaders are largely immune from what most persons in the world would consider common notions of justice.

The papers in this special issue highlight a number of important issues regarding the problem of white-collar and corporate crime in Asia, and entail topics ranging from accounting frauds, illegal trading activities in the mutual fund industry, cybercrime, enforcement efforts aimed at violations of intellectual property laws, comparative issues, and corporate crime more generally. Hong Lu, Bin Liang, and Melanie Taylor present a comparative analysis of cybercrime and enforcement efforts in the U.S. and China. As they point out, such cross-cultural analyses of cybercrime are extremely difficult to carry out due to evolving definitions of what is legal and what is outlawed, the hidden nature of the offenses, and different enforcement emphases and mechanisms. Using data collected over ten years from major newspapers in both countries, they build upon past research and pursue the following questions. What are the major characteristics of cybercrime and its enforcement measures? In what ways do cybercrime and enforcement efforts converge or diverge? And what are the underlying socio-legal factors that explain these patterns? They find that both the U.S. and China suffer from the evolving nature, of cybercrimes that almost appear to be truly boundless and global in nature and that offenders are similar in terms of demographic features, such as gender and age. Both countries have strengthened legislation and created special agencies to combat the high-tech nature of cybercrimes. Each nation's practices are rooted in its unique legal, cultural, and societal contexts which present major challenges to international collaboration in controlling offenses that have become increasingly transnational in nature.

Tomomi Kawasaki examines financial crime in Japan that takes a major toll on both individual victims and the nation's economy. He focuses on large investment frauds that have occurred from post-war Japan to the present as well as financial crimes that involve racketeers of boryokudans, or organized crime groups, more commonly known as yakuza. Kawasaki explains major forms of financial offending engaged in by organized criminals, 
including yamikin (loan sharks), sokaiya (shareholders who extort corporate funds), jiageya ("land sharks" who frighten tenants into vacating properties), and new forms of yakuza money crime that constitute major challenges to enforcement. He calls for more comprehensive legislation that applies to all forms of investment fraud in order to stem the tide of white-collar crime in Japanese society.

Haiyan Liu analyzes a number of aspects of the criminal enforcement of intellectual property rights (IPR) in China and focuses on trends and developments, including pressure from the U.S. to expand the criminalization of IP infringement. The article provides a comprehensive summary of the substantive criminal law regarding IP offenses in China and describes the main enforcement agencies responsible for the investigation and processing of IP crimes. Liu's findings show a steady pattern of rapid criminalization, including new statutes and judicial interpretations and notices, and increased enforcement of IP and related offenses. The study documents joint meetings, information exchanges, issuances of provisions, collaborative "strike-hard" enforcement campaigns, and other major efforts to facilitate inter-agency cooperation and to strengthen the criminal enforcement of IPR. These issues are considered within the context of problems in China's criminal justice system, including local protectionism, lack of respect for procedural justice and the protection of basic rights of defendants, inadequate training, professional incompetence, misconduct, and corruption.

Tokikazu Konishi examines major corporate scandals in the U.S. and Japan, focusing on the role of accountants and accounting fraud in allowing for the production of false financial reports that hid actual losses. He provides a detailed discussion of the corporate meltdowns involving three major companies; Enron, Kanebo, and Livedoor. The case histories highlight both the characteristics of frauds perpetrated by CPAs as well as the reactions to these crimes in both the U.S. and Japan. These scandals have led to deep distrust of corporate accounting in both societies. The analysis indicates differences in accounting frauds perpetrated in the two countries and considers how cultural variations play a major role in producing some distinctive outcomes.

Andrew Peterson examines conditions and structures that led to abuses in the American mutual fund industry and examines the risk for the occurrence of similar offenses in Japan. The American scandals unfolded in 2003 when a whistleblower alerted authorities to illegal and unethical trading practices between institutional investors and mutual fund companies. The abuses included late trading, market timing violations, illegal sales practices, and excessive fees, with damages estimated at well over $\$ 4$ billion per year. Peterson uses archival data to understand the regulatory conditions that allowed for illegal practices to proliferate throughout the American mutual fund industry and compares these conditions to those in Japan to assess the potential for similar abuses and how they might best be prevented.

It has often been pointed out that the only way criminology would be able to produce generalizations that were accurate beyond the borders of a single nation was to engage in comparative investigations in other cultures. One of the earliest such endeavors involved the study of youth gangs in different countries that alerted scholars to the fact that explanatory paradigms had to be seriously re-formulated when it became evident that they had only parochial application, and that the interpretations varied when comparative studies were conducted in, for instance, Japan, Britain, Russia, and Senegal.

The study of white-collar and corporate crime is only beginning to transcend local boundaries. In part, the effort is challenged by the often complex and arcane nature of the subject, differing laws, and, almost invariably, cultural attitudes and power politicsmatters much less dominant in regard to so-called street or common crimes such as murder, 
rape, and burglary. This issue of the Journal offers a glimpse into the rich results that can be obtained when economic offenses in Asian countries are examined in terms of the setting in which they occur and in regard to comparative information.

Open Access This article is distributed under the terms of the Creative Commons Attribution Noncommercial License which permits any noncommercial use, distribution, and reproduction in any medium, provided the original author(s) and source are credited.

\section{References}

BBC Monitoring Asia Pacific. (2005a). Official says China prosecuted 30,788 government officials in 2004. Xinhua news agency, Beijing, March 9.

BBC Monitoring Asia Pacific. (2005b). Chinese official assesses economic crime in state-owned banks. Xinhua news agency, Beijing, October 22.

Chinadaily.com.cn. (2006). Repatriation of suspects shows justice 'will prevail.' May 24.

Glionna, John M. (2010). Convicted tycoon's return to Samsung brings sense of déjà vu. Los Angeles Times, March 28: A4.

Johnson, D. T. (2003). American law in Japanese perspective. Law \& Social Inquiry, 28(3), 771-798.

Kerbo, H. R., \& Inoue, M. (1990). Japanese social structure and white collar crime: recruit cosmos and beyond, Deviant Behavior, 11(139-154), 148.

McGivering, Jill. (2006). China ‘selling prisoners' organs’ BBC News, April 19. http://news.bbc.co.uk/2/hi/ asia-pacific/4921116.stm

Pontell, H. N., \& Geis, G. (2007). Black Mist and White Collars: Economic Crime in the United States and Japan. Asian Journal of Criminology, 2, 111-126.

Sutherland, Edwin H. 1955. White Collar Crime. Translated by Ryushi Hirano and Koji Iguchi. Tokyo: Iwanami Shoten.

Yu, O. (2008). Corruption in China's economic reform: a review of recent observations and explanations. Crime, Law and Social Change, 50, 161-176.

Zhang, L., Messner, S. F., \& Liu, J. (2008). A critical review of recent literature on crime and criminal justice in China: research findings, challenges, and prospects (Introduction). Crime, Law and Social Change, $50,125-130$.

Zimring, Franklin E. \& Johnson, David T. (2007). On the comparative study of corruption. Pp. 456-473 in Henry N. Pontell and Gilbert Geis (eds). International Handbook of White-Collar and Corporate Crime. NY:Springer. 